Original Research Paper

\title{
Meat Productivity of Hereford Breed Calves with the Carbohydrate Complex Diet
}

\author{
${ }^{1}$ Irina Mironova, ${ }^{1}$ Vladislav Beresnev, ${ }^{1}$ Hamit Tagirov, ${ }^{1}$ Zulfiya Galieva, \\ ${ }^{2}$ Andrey Gaag and ${ }^{3}$ Ruzel Khabibullin \\ ${ }^{1}$ Department of Technologies of Meat, Dairy Products and Chemistry, Federal State Budgetary Educational Establishment of \\ Higher Education "Bashkir State Agrarian University", Ufa, Russian Federation \\ ${ }^{2}$ Department of Economics and Law, Tomsk Agricultural Institute - Branch Federal State Budgetary Educational Establishment \\ of Higher Education "Novosibirsk State Agrarian University", Tomsk, Russian Federation \\ ${ }^{3}$ Department of Physical Education, Sports and Tourism, Federal State Budgetary Educational Establishment of Higher \\ Education "Bashkir State Agrarian University", Ufa, Russian Federation
}

\author{
Article history \\ Received: 06-09-2021 \\ Revised: 25-10-2021 \\ Accepted: 12-11-2021 \\ Corresponding Author: \\ Irina Mironova \\ Department of Technologies of \\ Meat, Dairy Products and \\ Chemistry, Federal State \\ Budgetary Educational \\ Establishment of Higher \\ Education "Bashkir State \\ Agrarian University", Ufa, \\ Russian Federation \\ Email: \\ irinamironova49@rambler.ru
}

\begin{abstract}
In current conditions, we are increasing beef production, including through the organization of full-fledged feeding of growing young animals. The literature analysis indicates that the science of feeding contains a large set of experimental and practical data on the effect of feeding on the productivity of livestock. However, the questions about the influence of various types of feed additives on the composition of finished products have not been sufficiently worked out, which determined that the task we set is relevant. In this regard, we have set ourselves to increase the productivity of young animals by enriching the diet with a new carbohydrate complex. The paper considers changes in live weight, slaughter indicators, the carcass's morphological composition and chemical indicators of the average minced meat sample of young Hereford cattle, consuming different dosages of the Felutsen complex. The analysed additive stimulated animal growth due to a better nutrient intake. The intergroup difference between animals at the age of one and a half years reached 14.60-29.4 kg (2.82-5.65\%). Compared to the control animals, the experimental ones receiving an average dosage had higher hot carcass and slaughter weights by $5 \%$ and the slaughter yield by more than $1 \%$. The carcass's morphological composition also improved with higher meat proportion and less bone and connective tissue. A comparative analysis of minced meat samples' chemical composition showed the differences in the dry matter, fat, protein and ash content. "Felutsen" K 2-4 supplement at a dose of 50,100 and $150 \mathrm{~g} / \mathrm{animal} / \mathrm{day}$ (from 6 to 12 months), "Felutsen" K 2-6 at a dose of 100, 150 and $200 \mathrm{~g} / \mathrm{animal} / \mathrm{day}$ (from 12 to 18 months) had the greatest effect. The conducted study found that a carbohydrate complex in the diet of calves raised for meat production positively affects growth and development indicators. It contributes to better slaughter qualities, more intensive muscle tissue development resulting in a better morphological composition of carcasses.
\end{abstract}

Keywords: Calves, Carbohydrate Complex, Chemical Composition, Meat, Morphological Composition

\section{Introduction}

The annual rise of the world population brings in food supply issues. They can be addressed by the animal breeding sector that provides raw materials to processing enterprises. In turn, agroindustry activities should be aimed at increased meat production, including beef. Thus, the Russian output of strategic products does not meet the physiological needs of the population, although its meat market is one of the largest in the country and globally Agriculture, Food and Rural Development 2006 (Chabaev et al., 2018; Gorelik et al., 2019; Gorlov et al., 2020) United Nations Administrative Committee on Coordination Sub Committee on Nutrition, 2000 (World Health Organization, 2003). 
It is important to note that the cattle breeding technology is differentiated by region and the industry's development potential has not been realised in full. In these terms, animal nutrition quality and the maximum realisation of the genetic potential of animal productivity becomes almost essential (Barendse et al., 2007; Federation-Bif, 1996; Bourdon, 1997; Khasanov et al., 2019; Lyashuk et al., 2017).

There are certain impediments to the industry development related to providing animals with nutritionally balanced feed, their qualitative composition and new biologically effective feed additives in the diets (Andreeva et al., 2018; Arthur et al., 2001; Khabibullin et al., 2019).

Of particular concern is animal health, the end product quality and the realised genetic potential of farm animals (Arango et al., 2002; Ponzoni and Newman, 1989; Wang et al., 2006; Wilson, 1980; Zerbino and Frahm, 1983).

There is a wide variety of additives at international and domestic markets. Previous research has revealed the beneficial effects of supplements that provide the body with all the necessary nutrients and speed up energy metabolism in animal bodies (Physicians Committee for Responsible Medicine, 2018; Rose, 2019) U.S. National Library of Medicine 2020.

Feed additives provide animals with a sufficient amount of nutrients as proteins, carbohydrates, minerals, vitamins, enzyme preparations, flavouring agents. Supplements can be classified according to their intended use. There are additives for cattle (cows, sheep, goats), pigs, poultry, rabbits. All groups of additives have a distinct and unique composition since they are saturated with active substances designated for a specific animal or bird. In addition, ingredients vary depending on the animal age or the source compounds. There are plant, mineral, balanced additives and supplements with technological properties (Carbone and Pasiakos, 2019; Galin et al., 2020; Johansson, 2018; Ventsova and Safonov, 2021; Wu et al., 2014).

The most promising is a cattle feed additive under the trade name "Felutsen", presented in series: Mineral, preventive, energy, protein and carbohydrate (Kalaeva et al., 2019; Zinnatullin, 2016).

Its carbohydrate complex is of particular interest for its fermentable carbohydrates foster the nutritional value of feed.

Feed carbohydrates, being a source of energy for ruminants, are converted into volatile fatty acids (acetic, propionic, butyric) under the action of pre-ventricular microorganisms. Then they are absorbed by the mucous membrane, enter the blood and participate in metabolic processes (Karamayev et al., 2019).

Nowadays, we have the task of increasing beef production, relying on experimental and practical data on the effect of feeding on livestock productivity. However, there are still unresolved issues of the influence of various types of feed additives on the composition of finished products. Insufficient database and lack of depth of their elaboration determined the relevance of the set goal and task.

Based on the preceding, the study aimed to increase the meat productivity of Hereford bulls by enriching their diet with a carbohydrate complex and establishing its optimal dosage. The research tasks included:

- to study the characteristics of the growth of young Hereford breed by age periods, consuming different dosages of a new energy supplement

- $\quad$ to determine the meat productivity and the quality of the meat of the experimental young animals that received the tested feed additive

\section{Materials and Methods of Studies}

\section{Research Materials}

The object of observation was 6-month-old Hereford bull calves. The initial period of a scientific and economic experiment involved preparing the same maintenance conditions for 40 selected animals. The animals were divided into four groups according to the similarity principle.

\section{Research Design}

The control (I) group of calves received a diet without additives and the experimental (II, III and IV) groups got additives.

The young animals of the experimental groups were fed with the balanced carbohydrate complex "Felutsen". The experimental bull calves got K 2-4 preparation at a dose of 50,100 and $150 \mathrm{~g}$ per animal per day from birth until the age of 12 months and K 2-6 at a dose of 100,150 and $200 \mathrm{~g}$, respectively, in the remaining period (from 13 to 18 months).

All tested additive samples are powders and intended for calves up to one year and older, respectively. The basis of the complexes is fermentable carbohydrates, highly purified sodium chloride, calcium, sulfur, phosphorus, magnesium, protected vitamins $\mathrm{A}, \mathrm{E}, \mathrm{D}_{3}$. The complex "Felutsen" K 2-6 is additionally enriched with copper, cobalt, zinc, iodine, manganese, selenium (Tagirov et al., 2018; Vorobyov et al., 2019).

The component composition of carbohydrate complexes is designed to increase the diet's energy value, balance the sugar-protein and energy-protein ratio, vitamin and mineral enrichment, improve digestion, digestibility of feed nutrients and, consequently, strengthen immunity, proper development of bones and tissues, maintain a healthy condition of the skin, coat and hooves.

The research was conducted under the climatic conditions of the Tomsk region in the Russian Federation. The experiment was set out in 2018-2019. The studies were carried out at LLC "Berezovskaya Ferma" in the Pervomaisky District of the Tomsk Region. 


\section{Research Methods}

The calf growth was recorded in monthly dynamics using the method of individual weighing before feed consumption.

The post-slaughter assessment and meat productivity analysis were performed on three animals from the group using domestic methods. The meat productivity of young animals was evaluated by control slaughter of three heads from each group according to the methodology proposed by the All-Union Academy of Agricultural Sciences named after V.I. Lenin, All-Russian Scientific Research Institute of Animal Husbandry named after Academician L.K. Ernst, the All-Russian Scientific Research Institute of the Meat Industry named after V.M. Gorbatov.

Average samples were taken from the carcass pulp to study their chemical composition, following the methodological recommendations of the All-Russian Research Institute of Beef Cattle Breeding, now the Federal Scientific Center for Biological Systems and Agricultural Technologies of the Russian Academy of Sciences 1984. The right half carcasses were deboned to examine their morphological composition after being cooled at a temperature of $2-4^{\circ} \mathrm{C}$ for two days. Morphology was recorded according to absolute data and calculated relative values of muscles, bones and tendons.

Meat quality characteristics were assessed by the indicators of moisture, protein, fat and ash of their average on samples taken from minced meat.

\section{Statistical Analysis}

All the received digital values were processed by the variational statistical method in Microsoft Office Excel 10.0. Statistical comparison of the results was carried out using the Student's criterion. The significance level (P) was assumed to be less than or equal to 0.05 .

\section{Results}

One of the most critical indicators of meat productivity in animal science is the animal's live weight. It provides direct insight into additive efficacy and animal maintenance conditions in economic terms.

The positive effect of the carbohydrate complex "Felutsen" is confirmed by monthly weighing indicators of young animals (Table 1).

When the animals were six-month-old, their weights did not differ much and ranged from $187.8 \pm 0.70$ to $188.1 \pm 1.67 \mathrm{~kg}$.

At nine months, bull calves of the third experimental group showed the highest weight gain, amounting to $277.9 \pm 0.79 \mathrm{~kg}$, while the control group animals reached $270.1 \pm 1.98 \mathrm{~kg}$.

At the age of 12 and 15 months, the third experimental group fed the carbohydrate complex "Felutsen" K 2-4 had increased live weight by 3.9 and $4.7 \%$, respectively, compared with the control animals.

The carbohydrate complex "Felutsen" K 4-5 administered to young experimental cattle at 18 months ensured the highest indicators of live weight, amounting to $547.7 \pm 1.48 \mathrm{~kg}$ in the third group.

According to live weight data, the highest efficacy was shown when using $100 \mathrm{~g}$ of "Felutsen" K 2-4 and $150 \mathrm{~g}$ of $\mathrm{K} 2-6$.

Meat productivity is usually assessed after the slaughter of three animals from the group according to their carcass's morphological composition (Fig. 1).

The control slaughter revealed that the young animals of the third experimental group getting the carbohydrate complex "Felutsen" K 4-5 in a daily dose of $150 \mathrm{~g}$ had the best slaughter qualities.

The hot carcass weight of experimental bull calves in the third and fourth groups significantly exceeded similar indicators in the control group by 5.4 and $4.8 \%$, respectively.

Animals of the third experimental group had the highest carcass yield, amounting to $57.2 \%$, while young stock in the control group had the lowest.

Compared to the control group, experimental bull calves fed with the carbohydrate complex "Felutsen" K 45 had more internal raw fat by $3.5 \%$.

The slaughter weight of young animals in the third experimental group was the highest and exceeded the control animals by $5.5 \%$. Their slaughter yield was more by $1.3 \%$.

The bull calves of the third experimental group showed the best slaughter qualities.

When fattening young animals, it is necessary to take into account their growth and development patterns. If all the necessary maintenance and feeding conditions in raising young stock for meat are met, it is possible to get animals with the best carcass morphological composition. Muscle and adipose tissues being biologically valuable in the morphological composition of the carcass determine its nutritional and energy value.

The carcass morphological composition indicators provide the total characteristics of animal meat qualities and meat composition assessment.

As stated earlier, the carbohydrate complex "Felutsen" has a different effect on the growth and development rate when given to experimental animals in different dosages. In turn, this affected the morphological composition of the carcass (Fig. 2, 3).

The highest yield of pulp was in carcasses of the bull calves in the third and fourth experimental groups, amounting to 80.31 and $80.29 \%$, while it reached $79.64 \%$ in the control samples.

The proportion of muscle tissue had an insignificant intergroup difference in groups II, III and IV and amounted to $70.69,70.88$ and $70.88 \%$, respectively.

The fat content in half carcasses varied from 9.01 to $9.43 \%$, being higher by $0.09-0.42 \%$ in the experimental animals. 


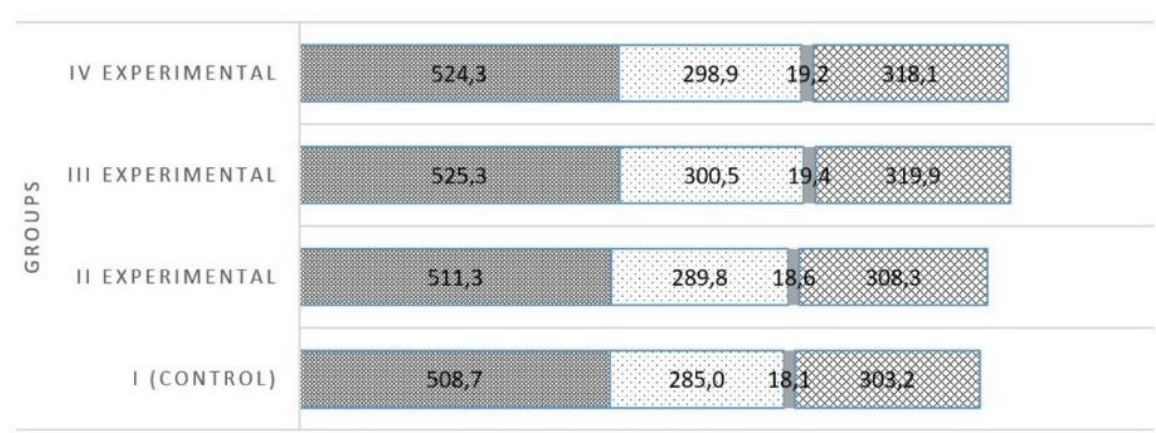

Pre-slaughter live weight, $\mathrm{kg} \quad \square$ New carcass weight, $\mathrm{kg} \quad$ Internal fat mass, $\mathrm{kg} \otimes$ Slaughter weight, $\mathrm{kg}$

Fig. 1: The results of the control slaughter of experimental calves

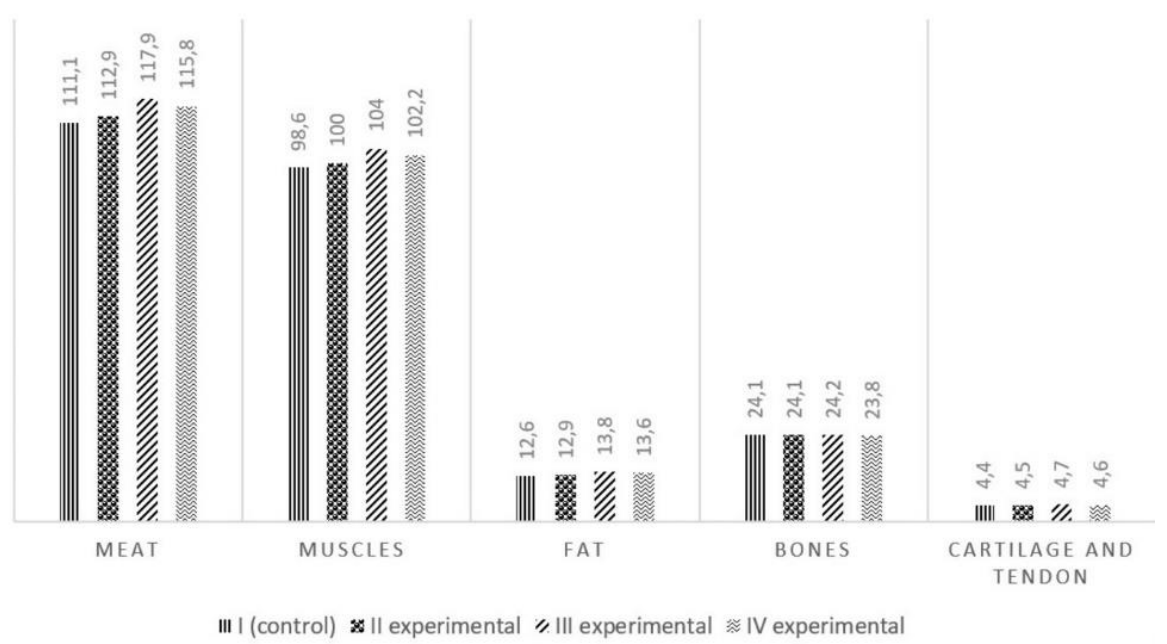

Fig. 2: Morphological composition of half-carcasses of calves at the age of 18 months, $\mathrm{kg}$

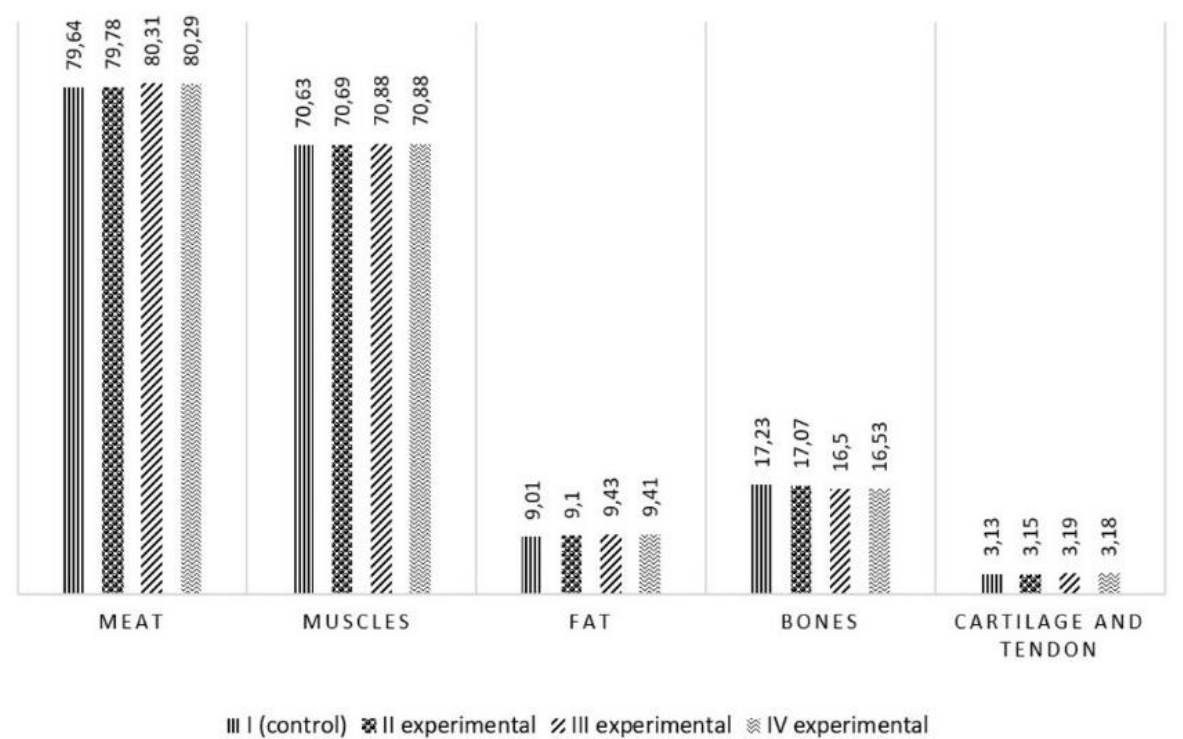

Fig. 3: The ratio of tissues in a half-carcass of calves at the age of 18 months, $\%$ 


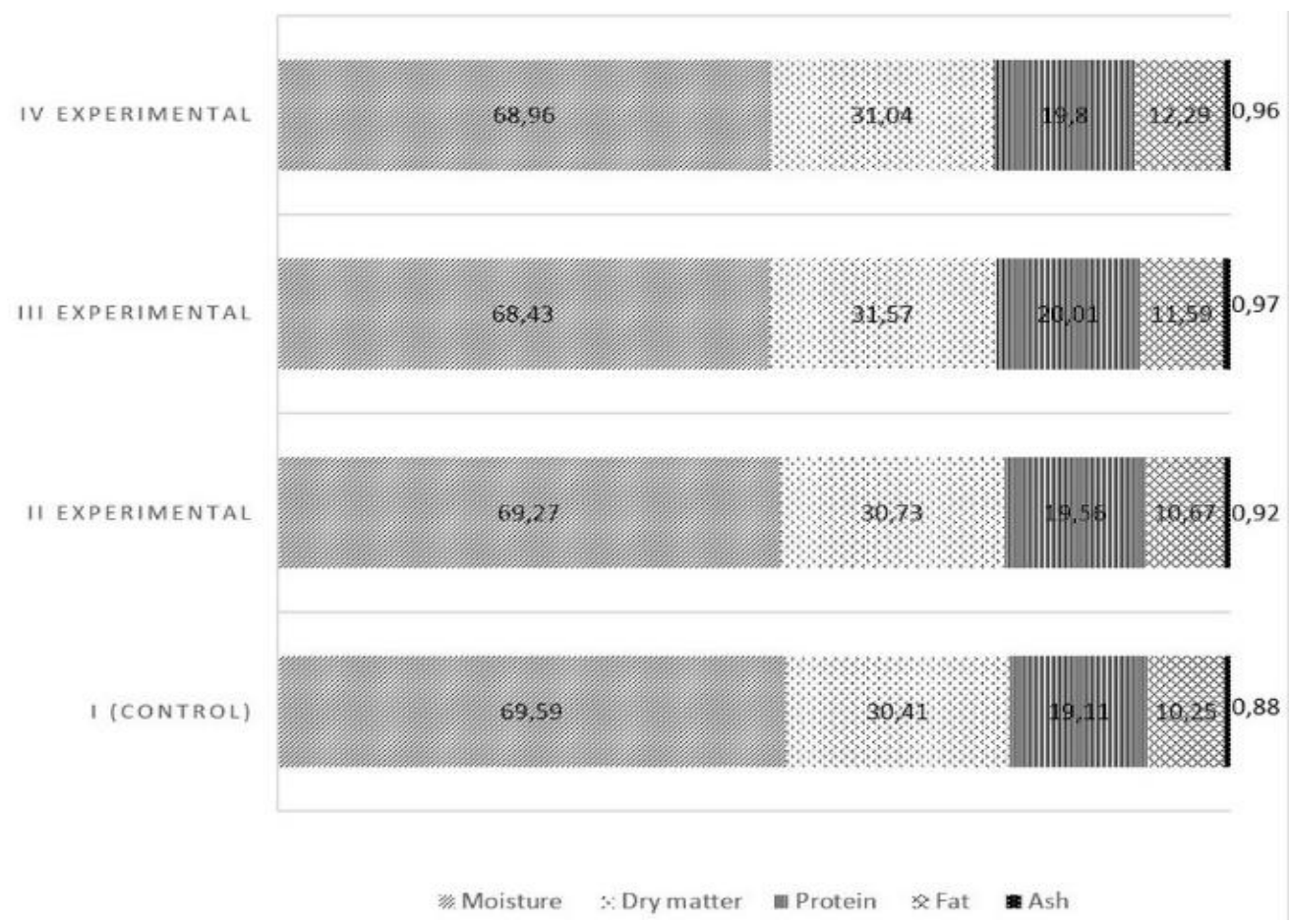

Fig. 4: Chemical composition of the average sample of minced meat of experimental calves, \%

Table 1: Live weight of calves by age, $\mathrm{kg}$

\begin{tabular}{|c|c|c|c|c|}
\hline \multirow[b]{2}{*}{ Age, months } & \multicolumn{4}{|l|}{ Group } \\
\hline & I (control) & $\begin{array}{l}\text { Experimental } \\
\text { II }\end{array}$ & III & IV \\
\hline$\overline{6}$ & $188.1 \pm 1.67$ & $188.0 \pm 0.65$ & $187.8 \pm 0.70$ & $188.0 \pm 0.67$ \\
\hline 9 & $270.1 \pm 1.98$ & $274.4 \pm 0.65$ & $277.9 \pm 0.79$ & $277.0 \pm 1.63$ \\
\hline 12 & $358.8 \pm 1.63$ & $365.6 \pm 1.93$ & $372.8 \pm 1.80$ & $368.2 \pm 1.33$ \\
\hline 15 & $447.2 \pm 2.10$ & $458.0 \pm 2.34$ & $468.4 \pm 1.48$ & $461.3 \pm 2.40$ \\
\hline 18 & $518.4 \pm 1.91$ & $533.0 \pm 2.65$ & $547.7 \pm 1.48$ & $540.2 \pm 2.41$ \\
\hline
\end{tabular}

Although the bone tissue belongs to the non-food part of the carcass, general animal growth depends on its development. The absolute bone weight did not differ much in groups, while the relative bone content in the control samples was higher by $0.16-0.73 \%$.

One of the most important indicators of the qualitative composition of meat is examining the chemical composition of an average sample of minced meat. The composition of the average sample of meat by chemical indicators involves analysing such vital components as water, protein, fat, ash and others. The conducted study demonstrated that the carbohydrate complex "Felutsen" had a specific effect on the meat composition (Fig. 4).

The carcass pulp part protein significantly differed in the intergroup aspect with the predominant position of animals in the experimental groups by $0.45-0.90 \%(\mathrm{P} \leq 0.01)$.

The amount of fat in meat samples of the experimental groups III and IV was 11.59 and $12.29 \%$, which is higher by $1.34 \%(\mathrm{P}<0.05)$ and $2.04 \%(\mathrm{P}<0.05)$, respectively, than in control.

One of the meat maturity indicators is the fat content in the carcass and decreased moisture. Moisture content was higher in control samples (by $0.32-1.16 \%$; $\mathrm{P} \leq 0.05$ 0.01 ), fat content was bigger in experimental samples (by $0.42-2.04 \% ; \mathrm{P} \leq 0.05)$.

The dry matter content varied depending on the group from 30.41 to $31.57 \%$, with experimental samples leading by $0.32-1.16 \%(\mathrm{P} \leq 0.05-0.01)$. The ash content in the carcass chemical composition of the experimental groups III and IV was the highest. It amounted to 0.97 and $0.96 \%$, exceeding the control group by $0.09 \%(\mathrm{P} \leq 0.01)$ and $0.08 \%(\mathrm{P} \leq 0.01)$, respectively.

\section{Discussion}

Adequate feeding of animals presupposes the maximum satisfaction of the body's needs for the necessary nutrients. It is practically impossible to achieve 
this in the farm conditions, even with the availability of good quality forage. In this regard, in the overwhelming majority of cases, to achieve high productivity of animals in the practice of animal husbandry, feed additives are used, including biologically active substances. These drugs can increase metabolic processes possessing a broad spectrum of action, leading to an increase in production. The effectiveness of biologically active substances is so great that it allows you to get an additional $60 \%$ of the production without increasing feed consumption.

In this regard, a particular interest, in our opinion, is the study of the influence of feeding an energy supplement on the meat productivity and quality of meat of young cattle. Therefore, in the conditions of LLC "Berezovskaya Ferma" in the Pervomaisky District of the Tomsk Region, a scientific and economic experiment was carried out on the Hereford gobies.

When conducting the scientific research, the existing current zootechnical, physiological and chemical research methods were used with the use of modern certified equipment, followed by processing of the obtained material by the method of variation statistics using the Student's t-test. The results of our research indicate that the use of a balanced carbohydrate complex "Felucene" in the composition of animal diets has a specific effect on the intensity of their growth.

At the age of 18 months, the live weight in the experimental groups was $518.4-547.7 \mathrm{~kg}$, the differences between which were quite significant. Compared with their peers in the control group, they had an advantage in live weight at the end of the experiment in experimental I by $14.6 \mathrm{~kg}(2.82 \%)$, in experimental II - by $29.3 \mathrm{~kg}$ $(5.65 \%)$ and in experimental III - by $21.8 \mathrm{~kg}(4.20 \%)$.

For an objective assessment of the productivity of animals, slaughter indicators were used, which can fully show the morphological composition, biochemical and qualitative characteristics of the products obtained. The results of the controlled slaughter showed that the best slaughter qualities characterized the gobies of the experimental groups that received the test fodder in the diet. The heaviest carcasses were obtained from the gobies of the III experimental group. By carcass weight, they exceeded young animals from the control group by $5.5 \mathrm{~kg}$ or $5.43 \%$, from experimental group II - by $10.2 \mathrm{~kg}$, or $3.52 \%$ and from experimental group IV - by $1.6 \mathrm{~kg}$, or $0,54 \%$.

When the gobies were fed the feed additive in their bodies, the internal raw fat was synthesized more by $0.5-1.3$ $\mathrm{kg}$, or $2.76-7.18 \%$, with a more significant difference in favour of the gobies in the III and IV experimental groups.

The slaughter weight of the gobies of the II experimental group was higher by $5.6 \mathrm{~kg}(1.85 \%)$, III - by $16.7 \mathrm{~kg}(5.51 \%)$ and IV - by $14.9 \mathrm{~kg}(4.91 \%)$, in comparison with the control animals. In general, the best slaughter qualities were in the gobies of the II and III experimental groups, which received the studied preparation under the trademark "Felucen" in the diet.
It is known that the mass of carcasses and the yield of slaughter products do not fully characterize the quality side of the products obtained. It is necessary to study its morphological composition to obtain a more complete picture of the changes occurring in the carcasses of the young animals under study. The morphological composition of carcasses characterizes the meat qualities of animals in terms of the ratio of muscle, fat, connective and bone tissues. These tissues characterize both the quantitative and qualitative aspects of the meatiness of the animal.

The morphological composition of the carcasses showed that the carcasses of the gobies of the II experimental group contained more flesh - by $1.8 \mathrm{~kg}(1.62 \%)$, in III - by $6.8 \mathrm{~kg}(6.12 \%)$ and in the IV experimental group by $4.7 \mathrm{~kg}$ $(4.23 \%)$ than in control peers.

When studying the chemical composition of the average sample of minced meat, it was found that the protein content in the gobies flesh of carcasses in various groups varied within $19.11-20.01 \%$ with a significant superiority in favour of peers of the III and IV experimental groups. They received medium and large doses of the carbohydrate complex "Felucene".

The amount of fat in the flesh of the bulls of the III and IV experimental groups was the maximum. It amounted to 11.59 and $12.29 \%$, which is 0.92 and $1.62 \%$ more than in the I experimental group and 1.34 and 2.04 $\%$ than in the control group.

In the research, results were obtained indicating the effectiveness of feed additives in feeding cattle, which improved livestock raw materials' productivity and quality indicators. Similar results were obtained by, Zinnatullin (2016), Andreeva et al. (2018).

Thus, the inclusion of a carbohydrate complex in calves' diet when raised for meat has a positive effect on growth and development indicators. It contributes to the achievement of better slaughter qualities, more intensive development of muscle tissue, which made it possible to obtain carcasses from them with a better morphological composition. Also, it is noted that a considerable accumulation of nutrients characterized by the composition of the meat. At the same time, feeding with higher and average doses of the studied supplement showed the best efficiency.

\section{Conclusion}

This investigation shows that a carbohydrate complex in the diet of beef calves positively influences young cattle's growth and development. It enhances slaughter qualities and muscle tissue development, providing an improved morphological composition of carcasses. Meat composition can be characterised by accumulated nutrients. The best additive efficacy was achieved when animals were fed with larger and average doses of the studied supplement. 


\section{Funding Information}

This research did not receive any specific grant from funding agencies in the public, commercial, or not-forprofit sectors.

\section{Author's Contributions}

Irina Mironova: Methodology, Validation, Formal Analysis, Data Curation, Writing-Original Draft Preparation.

Vladislav Beresnev: Conceptualization, Validation, Resources, Data Curation, Writing-Review \& Editing.

Hamit Tagirov: Software, Validation, Investigation, Data Curation, Writing-Original Draft Preparation.

Zulfiya Galieva: Conceptualization, Validation, Investigation, Resources, Writing-Original Draft Preparation.

Andrey Gaag: Methodology, Software, Validation, Writing-Review \& Editing, Visualization.

Ruzel Khabibullin: Methodology, Validation, Formal Analysis, Resources, Writing-Review \& Editing.

\section{Ethics}

The investigation exploited standard research methods based on the minimum necessary number of animals to cause them the least possible suffering. The examined livestock was serviced under Russian and foreign instructions and recommendations (Order No. 755 of 12.08.1977 of the USSR Ministry of Health; Institute of Laboratory Animal Resources, Commission on Life Sciences, National Research Council, National Academy Press Washington, 1996, Institute of Laboratory Animal Resources, 1996; USSR Ministry of Health, 1987 (World Health Organization, 2003; Wu et al., 2014)

\section{References}

Andreeva, A. V., Nikolaeva, O. N., Ismagilova, E. R., Tuktarov, V. R., Fazlaev, R. G., Ivanov, A. I., ... \& Khakimova, A. Z. (2018). Effect of probiotic preparations on the intestinal microbiome. Journal of Engineering and Applied Sciences, 13(S8), 6467-6472. doi.org/10.3923/jeasci.2018.6467.6472

Arango, J. A., Cundiff, L. V., \& Van Vleck, L. D. (2002). Comparisons of Angus-, Braunvieh-, Chianina-, Hereford-, Gelbvieh-, Maine Anjou- and Red Poll-sired cows for weight, weight adjusted for body condition score, height and body condition score. Journal of animal science, 80(12), 3133-3141. doi.org/10.2527/2002.80123133x

Arthur, P. F., Archer, J. A., Johnston, D. J., Herd, R. M., Richardson, E. C., \& Parnell, P. F. (2001). Genetic and phenotypic variance and covariance components for feed intake, feed efficiency and other postweaning traits in Angus cattle. Journal of animal science, 79(11), 2805-2811. doi.org/10.2527/2001.79112805x
Barendse, W., Reverter, A., Bunch, R. J., Harrison, B. E., Barris, W., \& Thomas, M. B. (2007). A validated whole-genome association study of efficient food conversion in cattle. Genetics, 176(3), 1893-1905. doi.org/10.1534/genetics.107.072637

Bourdon, R. M. (1997). Understanding animal breedingPrentice Hall. Inc. Upper Saddle River, New Jersey.

Carbone, J. W., \& Pasiakos, S. M. (2019). Dietary protein and muscle mass: Translating science to application and health benefit. Nutrients, 11(5), 1136. doi.org/10.3390/nu11051136

Chabaev, M. G., Nekrasov, R. V., \& Romanov, V. N. (2018). Milk productivity, metabolic processes and reproduction rates in highly productive cows under the influence of protected L-carnitine. Sel'skokhozyaistvennaya biologiya, 53(6), 1169-79.

Federation-Bif, B. I. (1996). Guidelines for uniform beef improvement programs. Colby: W\&BS.

Galin, P., Galyaveeva, A., Bataev, H., \& Safonov, V. (2020). The role of micronutrients and vitamins in the prevention and remote treatment of heart failure. Revista Latinoamericana de Hipertension, 15(1), 2632 doi.org/10.5281/zenodo.4074201

Gorelik, O., Rebezov, M., Gorelik, A., Harlap, S., Dolmatova, I., Zaitseva, T., ... \& Novikova, N. (2019). Effect of bio-preparation on physiological status of dry cows. International Journal of Innovative Technology and Exploring Engineering, 8(7), 559-562. https://elibrary.ru/item.asp?id=39696144

Gorlov, I. F., Belyaev, A. I., Slozhenkina, M. I., Mosolova, N. I., Zlobina, E. Y., Randelin, A. V., ... \& Sherstyuk, B. A. (2020). New Synbiotic-Mineral Complex in Lactating Cows' Diets to Improve Their Productivity and Milk Composition. Iranian Journal of Applied Animal Science, 10(1), 31-43. http://journals.iau.ir/article_671587.html

Johansson, G. (2018). Protein deficiency-a rare nutrient deficiency. Lakartidningen, 115. https://europepmc.org/article/med/29786804

Kalaeva, E., Kalaev, V., Efimova, K., Chernitskiy, A., \& Safonov, V. (2019). Protein metabolic changes and nucleolus organizer regions activity in the lymphocytes of neonatal calves during the development of respiratory diseases. Veterinary world, 12(10), 1657. doi.org/10.14202/vetworld.2019.1657-1667

Karamayev, S. V., Bakayeva, L. N., Balakirev, N. A., Demin, V. A., Karamayeva, A. S., Soboleva, N. V., ... \& Baimukanov, D. A. (2019). Quality of colostrum in dairy breed cows with different dairy productivity. Научный журнал «Вестник НАН РК», (3), 72-84. doi.org/10.32014/2019.2518-1467.71

Khabibullin, R., Khabibullin, I., Yagafarov, R., Bakirova, A., Fazlaev, R., Karimov, F., ... \& Tuktarov, V. (2019). The influence of dietary supplements on the adaptive processes in animals after physical stress. Bulgarian Journal of Agricultural Science, 25(S2), 105. https://www.agrojournal.org/25/02s-14.pdf 
Khasanov, E. R., Gabitov, I. I., Mudarisov, S. G., Khamaletdinov, R. R., Rakhimov, Z. S., Akhmetyanov, I. R., ... \& Musin, R. Z. (2019). Justification of parameters of seed treater with an eccentrically fixed drum influencing the motion character and seed treatment modes. Bulgarian Journal of Agricultural Science, 25(2), 119-128. http://www.agrojournal.org/25/02s-15.pdf

Lyashuk, R. N., Mikhailova, O. A., Moshkina, S. V., \& Samoilov, D. A. (2017). Zootechnical evaluation of cows using feed additives "Atpure" and "Cavelos energy". Bull. Kursk State Agric. Acad, 3(2), 23-28.

National Research Council. Institute of Laboratory Animal Resources. 1996. Guide for the care and use of laboratory animals.

Physicians Committee for Responsible Medicine. 2018. Protein-Energy Malnutrition. Nutrition Guide for Clinicians.

Ponzoni, R. W., \& Newman, S. (1989). Developing breeding objectives for Australian beef cattle production. Animal Science, 49(1), 35-47. doi.org/10.1017/S0003356100004232

Rose, A. J. (2019). Amino acid nutrition and metabolism in health and disease. doi.org/10.3390/nu11112623

Tagirov, K., Gubaidullin, N. M., Fakhretdinov, I. R., Khaziakhmetov, F. S., Avzalov, R. K., Mironova, I. V., ... \& Gizatova, N. V. (2018). Carcass quality and yield attributesvof bull calves fed on fodder concentrate" Zolotoi felutsen". Journal of Engineering and Applied Sciences, 13(S8), 6597-6603. doi.org/10.3923/jeasci.2018.6597.6603

Ventsova, I., \& Safonov, V. (2021). The role of oxidative stress during pregnancy on obstetric pathology development in high-yielding dairy cows. American Journal of Animal and Veterinary Sciences, 16(1), 7-14. https://elibrary.ru/item.asp?id=44980348
Vorobyov, V., Vorobyov, D., Polkovnichenko, P., \& Safonov, V. (2019). Evaluation of hematological and metabolic parameters in small ruminants with trace elements deficiency under different biogeochemical conditions. Worlds Vet. J, 9(4), 311-316. doi.org/10.36380/scil.2019.wvj39

Wang, Z., Nkrumah, J. D., Li, C., Basarab, J. A., Goonewardene, L. A., Okine, E. K., ... \& Moore, S. S. (2006). Test duration for growth, feed intake and feed efficiency in beef cattle using the Grow Safe System. Journal of Animal Science, 84(9), 2289-2298. doi.org/10.2527/jas.2005-715

Wilson, B. (1980). The quite Limousine revolution. Big Farm Management, 11, 51-52.

World Health Organization. (2003). Diet, nutrition and the prevention of chronic diseases: Report of a joint WHO/FAO expert consultation (Vol. 916). World Health Organization.

Wu, G., Fanzo, J., Miller, D. D., Pingali, P., Post, M., Steiner, J. L., \& Thalacker-Mercer, A. E. (2014). Production and supply of high-quality food protein for human consumption: Sustainability, challenges and innovations. Annals of the New York Academy of Sciences, 1321(1), 1-19.

Zerbino, P. J., \& Frahm, R. R. (1983). Relationships of ontest hip height with growth and carcass traits of Hereford calves. Animal Science Research Report, 177-180. http://beef.okstate.edu/research_reports/1983rr/8335.pdf

Zinnatullin, I. M. (2016). Productive qualities of calves when feeding them feed concentrate "Felutsene" K-6. Zootechnia, 8, 7-8. 